\title{
Complex language encounters: Observations from linguistically diverse South African classrooms
}

RINELLE EVANS

University of Pretoria

AILIE CLEGHORN

Concordia University

\section{Introduction $^{1}$}

In many parts of the world, including South Africa, teachers are facing new challenges due to rapidly increasing numbers of linguistic and culturally diverse learners in their classrooms. Such shifts point to the fact that language-in-education research needs to keep pace with rapid global, social, technological and demographic change. Although there is a large body of available research on second language teaching and learning, there remains a gap in the research on young children's experiences in today's multilingual/multicultural second language classrooms (Iannacci, 2006). It is this gap in the research that our study aims to address.

In this article we report on the initial observation phase of a longitudinal study that is exploring complex language encounters in grades R to 3 classrooms in pre-primary and primary schools in South Africa. Complex language encounters refer to teacher-learner exchanges that take place when neither teachers nor learners are first language speakers of the instructional language. In South Africa, English is the de-facto language of instruction despite official policy which advocates for additive bilingualism. However, the vast majority of teachers being trained today in South Africa are not native speakers of English. This is explained by the fact that less than $10 \%$ of South Africa's 44.8 million people report English as the first language, a situation not uncommon in several other African countries (Statistics South Africa, 2001). In this way, many teachers find themselves teaching in English, despite the fact that it is not their mother tongue nor that of their students.

This phase of the research took place during teaching practice visits to two linguistically and culturally diverse urban classrooms and one semi-urban preschool. The authors' observations centered on pedagogical matters, homing in on the situational and contextual use of language(s) as well as the content and placement of classroom materials. Several vignettes were gathered which illustrate how critical it is for teachers to possess first language ability in the language of instruction and to be cross-culturally competent. That is, in order to facilitate diverse learners' sense-making efforts, teachers need to know how to relate to them linguistically, culturally and conceptually. Although preliminary, the findings already point to themes that will be explored in the next phase of our research through analysis of video-recordings, semistructured interviews, and the collection of language biographies from teachers as well as learners. Ultimately, this research asks, and in due course will attempt to answer, what are the social and pedagogical consequences of complex language encounters for learners? What are the implications of these encounters for teacher education?

\footnotetext{
${ }^{1}$ This research project has been made possible by funding from South Africa's National Research Foundation and the University of Pretoria.
} 
For about 20 years, the authors' ethnographic eyes have been cast on the role of language in primary and pre-primary school settings, contributing a solid base of language-related research experience for the present study. During professional and research visits to classrooms in Kenya, Zimbabwe, and South Africa, exemplary teaching practices have been observed as well as missed opportunities for incidental learning (Cleghorn, Merritt \& Abagi, 1989; Cleghorn \& Rollnick, 2002; Evans, Gauton, Kaschula, Prinsloo, Ramagoshi \& Taljard, 2007). Regardless of the particular instructional context, language can be seen as the thread that ties teacher, text, materials, activity, use of space, and learner together in the overall process of meaning making (Prochner, Cleghorn \& Green, 2008).

\section{The South African Context of Early Education}

In South Africa, pre-primary education refers to pre-grade 1 education for learners 0 to 6 years of age (UNESCO, 2006). Pre-primary programs are of two types: Grade R (reception year) which refers to the school preparation year for 5 year olds and pre-grade $\mathrm{R}$ programs that cater for children 0 to 4 years of age.

The reception year or $\mathrm{R}$ grade was a recommendation contained in The White Paper on Education and Training (1995), and evolved out of the "National Early Childhood Development Project," implemented as a 3-year pilot project starting in 1995. It was recognized from the start that "the long history of discriminatory provision in this sector delivers a set of conditions that make it difficult to provide a quick-fix solution" (Republic of South Africa, 1997, p. 2). The Education White Paper \#5 on Early Childhood Education noted the persistence of inequality of provision and access to early childhood services (Republic of South Africa, 2001). The main priority was the establishment of a national system whereby, by 2010 all children entering grade 1 would have participated in an accredited reception year program. Until recently, the grade $\mathrm{R}$ was included in early childhood education programs, about $85 \%$ of which were community or home based, many operated by church groups and non-governmental organizations. The Ministry of Education (MoE) is in the process of removing the grade $\mathrm{R}$ from these settings and phasing them into the public primary school system, in order to provide access for all to a year of preparation for primary school, in line with efforts to democratize the country and educational opportunities. Grade R teachers are to be provided with in-service training and the MoE in conjunction with the Department of Health and Social Development, envisages an integrated service for children age 0 to 4 and for vulnerable children with special needs - the disabled, the poor and those affected or orphaned by HIV/AIDS.

The situation is still very much in flux as the plan to move all the grade Rs into regular public schools by 2010 has not yet been realized. This change is, however, likely to result in four-year olds in the early childhood centers becoming the group to be prepared for formal schooling, with a consequent reduction in age-appropriate play-based learning (Cleghorn \& Prochner, 2010). The extent to which this will include an even earlier introduction to English, due partly to pressure from parents, remains to be seen. It also remains to be seen if the MoE will promote a bilingual/multilingual school system that gives space to the eleven official languages, that is, nine African languages plus English and Afrikaans. This matter is particularly serious in urban schools where the linguistic diversity is further increased by the influx of many African refugee and migrant workers' children. The grade R to grade 3 classrooms where the present study has been conducted so far can be seen as typical of these multilingual classrooms.

There are several factors that complicate learners' initial experience with formal schooling, particularly in this context. In South Africa - certainly in urban areas -beginning school usually includes a shift from the home or community language to instruction in English. 
Despite a language-in-education policy that advocates but does not mandate initial mother tongue instruction (Probyn, 2009), as noted above, many parents want their children exposed to English as early as possible because they equate being competent in English with increased economic opportunity. Further evidence that English is becoming the preferred language of instruction is found in preschool teachers' tendency to use English when introducing children to the written word (Cleghorn \& Prochner, 2010). As is the case in many other non-anglophone countries, it seems that the establishment of literacy in the early years is thus linked to and complicated by the spread and power of English (Cummins, 2000a; Heugh, Siegrühn, Plüddemann, 1995; Phillipson, 1992; Tollefson, 1991).

Another complication stems from the fact that, as mentioned, very few South Africans report English as their first language. By implication, the majority of teachers have varying competencies as second language speakers of English and often do not know a single word of the children's home languages, especially in urban schools where the learners may represent as many as 14 different home languages. This lack of connection between home and school languages raises another concern: it is well established that when learners must shift abruptly from the home language to the language of instruction, home languages are at risk of being lost, with serious consequences for children's ethnic and personal identities as well as for the society as whole (Bailey \& Nunan, 1996; Cummins, 2000b; 2003b; Dlamini, 2007; Ramanathan, 2005; Soudien, 2007; Wong-Fillmore, 1991). How then, can teachers attend to children's learning and social needs under the circumstances described here? We keep this question in mind as we turn to the theoretical and conceptual underpinnings of this research.

\section{Conceptual Framework}

What actually happens when teachers and their learners engage with each other in a language which neither party can use with ease? What are the implications for teachers' professional development? We refer to complex language encounters rather than events since instructional interaction in this context is more often an unforeseen perplexing cognitive endeavor rather than a single, neutral occurrence. We furthermore define this term as any oral, visual or written interaction initiated within an instructional context. Complex language encounter pertains specifically to teacher-learner exchanges but does not exclude peer interaction or non-verbal messaging. Broadly, this definition also encompasses the cultural and conceptual shifts that accompany the often-unwitting process of acculturating learners into Western ways of knowing and behaving, in this case via English, as well as through contact with the implicit messages contained within some classroom materials (Cannella \& Viruru, 2004; Prochner, Cleghorn \& Green, 2008). This research thus adds to the extant literature on the oral, visual and written strategies that teachers could use for establishing meaning and fostering literacy, especially when learners are still acquiring the language of instruction as a second or as an additional language.

Our conceptual framework links three strands of research: First, we draw from languagein-education studies that point to teaching approaches that are suitable for diverse groups of learners in both the Majority and Minority worlds. Second, the language-literacy writings of the New Literacies Studies (NLS) group in England, South Africa, and the United States provide important conceptual input for this research. Third, we draw on the concept of 'border crossing' due to its linguistic, cultural and conceptual relevance to the work of teachers in diverse school settings. The sections below elaborate on each of these. 


\section{Language-in-Education}

Teaching approaches that are suitable for diverse groups of learners, include those that are designed for children from low-literate homes, children who have little or no contact with the language of instruction in the home community, and children who have recently arrived as immigrants or refugees. Extensive research has found that children are better served at school in the early years through their home language with a well-planned introduction of the instructional language, coupled with home-language maintenance unless they come from communities where a dominant and well-supported language is used, (Benson, 2004; Bunyi, 1999; Cleghorn, 2005; Cleghorn \& Rollnick, 2002; Cummins, 2003a \& b; Cummins \& Hornberger, 2007; Genesee, 2008; Iannacci, 2006; Stroud, 2002). That is, learning in linguistically diverse school settings is best achieved through one form of bilingual instruction or another. The development of literacy in two or more languages can help the learner to see different representations of the same idea, while also providing the skills to function later on in a range of social contexts. Evidence that the pedagogical and social results of a bilingual approach can thus be additive comes not only from 40+ years of research in Canada (mostly with middle class English-speaking children who have attended French immersion programs), but also from Bolivia, Ghana, Guinea-Bissau, Kenya, Malawi, Mozambique, Nigeria, and Zambia (Bamgbose, 1984; Benson, 2004; Bunyi, 1999; Collison, 1975; Cummins, 2000a; 1996; Cummins \& Corson, 1997; Hovens, 2002; Mateche, 1994; Peal \& Lambert, 1962; Stroud, 2002; Williams, 1998). For example, Benson (2004) and Stroud (2002) report that parent communities in West Africa favor home language maintenance efforts within the school as long as their children also acquire the language that will provide them with access to higher education and economic opportunities. Unfortunately, too often political pressure for all instruction to be in English comes too early in the schooling process and is compounded by inadequate professional development of teachers.

\section{The New Literacy Studies}

The New Literacy Studies (NLS) group conceptualizes literacy as a plural phenomenon oral, visual, and written - with power dimensions. In this view, language encounters entail much more than simply learning to read, write, and calculate within classrooms. Indeed, such language encounters take place out of the classroom too, in school hallways, on the playground, with parents, and in home/community-based non-traditional literacy practices and events involving children as well as adults, thus expanding the context in which learning occurs (Barton, 1995; Barton, Hamilton \& Ivanic, 2000; Brandt \& Clinton, 2002; Collins \& Blot, 2002; Gee, 1986; 2000; 2008; Kim, 2003; Ong, 1991; Prinsloo \& Breier, 1996; Street, 2001a \& b; 2003; 2004).

Our understanding of children's early encounters with the scholastic requirements of reading and writing is provided by the work of Gee (1988), Olson (1990), Ong (1991) and Street (2001b, 2004), amongst others of the NLS group. Their position is that literacy alone (autonomously) is not a single neutral skill that once acquired brings personal development and empowerment. Nor is literacy a universal set of skills that can be imparted in uniform 'one size fits all' ways with predictable results. Rather, the NLS views literacy as always embedded in local social practices and in relations of power, with a frequent intermingling of the oral, visual and written, a position that Street (2001a) terms ideological. The ideological model offers a culturally sensitive view, since literacy needs and practices vary in many ways, for example, from rural to urban to semi-urban contexts. This approach forces us to ask questions like: What counts as literacy, what does not, and for whom? In what language does literacy count as 
literacy? (Dlamini, 2007; Egbo, 2000; Heath, 1983; Kendrick \& Jones, 2008; Stromquist, 1997; Sutton, 2001; Wenger, 1998).

The NLS plural conception of literacy implicitly contests the long-standing deficit view towards local, oral literacies in parts of Africa where an institutional, textbook-based Western form of schooling was introduced by colonial powers (Somjee, 2000), and remains accepted as the norm. Since oral literacies in South Africa remain associated in some educators' minds with race, such deficit views persist; policies for educational reform that have been borrowed from the West are still being institutionalized against the backdrop and legacy of South Africa's history of apartheid.

\section{Border Crossing}

Border crossing refers to the ability to shift conceptually as well as culturally, and when possible linguistically, between learners' and teachers' culturally-based attitudes and ways of looking at the world (worldviews). Knowledge about border crossing stands to provide teachers with strategies or tools for tapping into the cultural and linguistic capital that all children bring from home to the classroom (Aikenhead \& Jegede, 1999; Cobern, 1998; Giroux, 1992; Nsamenang, 2004; Serpell, 1993). Teachers need such tools to understand what children are experiencing, as they begin the process of acculturation towards Westernized ways of knowing and individualistic ways of behaving (Cleghorn \& Prochner, 2010; Waldrip \& Taylor, 1999).

As Krashen (1987) points out, language and culture intersect visibly in the classroom and authentic representation becomes key to an affective experience conducive to learning. Visual representations on (imported) wall charts or in picture books are often foreign to African children's frame of reference since they may depict situations or physical traits with which the learners cannot identify. Teachers therefore need strategies for bridging the gulf between the worldview as represented by the school and that of the learners (Alexander, 2000; Bernhard, Diaz \& Allgood, 2005; Ghosh, 1996).

It may well be that the school becomes a site of tension as the different worldviews experienced by the learners in their homes and communities meet in the classroom. As argued by Anderson-Levitt (2003) and Dachyshyn \& Kirova (2008), the essential differences between these worldviews (individualism, rationality, progress // communal, spiritual, holistic) need to be made explicit so that learners can go back and forth between the two with ease as they struggle to make sense of what goes on in school. While some children accomplish this with ease, many do not, requiring the teacher's help in this process.

\section{Vignettes}

The six vignettes presented here illuminate the central role that language and culture play in a Majority world context when children first enroll at school. In addition, they point to the complexity of classroom situations that increasing numbers of teachers must be prepared for today.

\section{Vignette 1}

The student teacher is white, her first language Afrikaans. All the preschoolers are black and speak any one of the nine official African languages. Instruction is in English. The teacher is not always understood but the children negotiate meaning: they watch each other, they ask each other, the cleaning lady explains unobtrusively in a language most of them understand. The teacher demonstrates and the activities seem to flow. 


\section{Vignette 2}

Many of the children are refugees from the Congo who speak French. They have all been seated together in the front rows of the class so that the teacher can "pay more attention" to them. The student teacher is Afrikaans-speaking but learnt basic French at school as a third language. The young faces light up instantly on her first day when she says Bonjour! During break, they crowd around her chatting eagerly.

\section{Vignette 3}

The Afrikaans-speaking student teacher uses an English song about ants to teach the concept of rhythm to a Grade 2 class in an inner city school. Fourteen different language backgrounds are represented in this class. The teacher goes through the lesson with the children chanting the song enthusiastically. Her assumption is the learners all know that the English word ant denotes a tiny, six-legged insect. Despite 30 minutes of repetitive engagement with the song, one child when asked to draw an ant could not until he was shown one crawling up the dustbin.

\section{Vignette 4}

A reading readiness exercise is taking place in a Grade $R$ classroom in a school on the outskirts of Pretoria. The teacher holds the large book up so that the children grouped in front of her on the floor can see the pictures. The book is called "My sister's wedding." All the characters are white and the wedding ceremony reflects a traditional Western style. The English text has been pasted over with a Setswana translation. The teacher uses Setswana to tell the story.

\section{Vignette 5}

The labels and captions of the didactic posters on the walls are written in English; the one pasted on the door reads 'The door is open' yet it is, in fact, shut. One word on another label is misspelled. One poster depicts the parts of a (white) body. The children are called one at a time to point to the different parts of the body, spoken by the teacher in Setswana, the home language of most of the children.

\section{Vignette 6}

The Afrikaans-speaking student teacher is reviewing shapes and colors. She intends to teach the word 'oval' but gives a clumsy and verbose explanation of egg-shaped. Her poorly phrased question was "Where do we also find eggs?" She had intended that learners point at other oval shapes in the classroom. However, a learner appropriately answers "In the shop." The teacher simply responds with an emphatic "no."

\section{Discussion and Conclusions}

These vignettes broadly encapsulate typical daily occurrences in many multilingual and culturally diverse classrooms worldwide, especially in those settings where the language of instruction represents a not fully mastered second language for many teachers. In all of these vignettes we can see some of the confusion that teachers and learners may experience in complex language encounters. So what have we learned that could provide student teachers as well as those already in the profession with practical means of facilitating the teaching-learning process in linguistically and culturally diverse instructional contexts?

In examining these vignettes we can see several strategies that students and teachers are currently using and a few strategies that teachers could implement to lessen learners' confusion. Two strategies that learners used to negotiate meaning are evident in Vignette 1. The children appeared to rely heavily on modeling i.e. watching and imitating those who understood. This coping mechanism is one strategy that could be encouraged by teachers and augmented by 
demonstration. In order for this to happen, however, teachers will need to relinquish control in certain stages of the lesson by permitting learners to gain clarity by talking amongst themselves.

The positive reaction of the young French speakers to a single word spoken in their language (a brief example of border crossing) (Vignette 2), affirms them, not as deficient speakers of English but rather as learners with a rich linguistic repertoire which they bring to school. An important and often unacknowledged resource in such contexts is the mother tongue speaker of a particular language. For example, most urban schools would have staff (not necessarily academic) and parents proficient in several of the languages spoken by the learners. These persons (as did the cleaning lady in Vignette 1) could assist in the classroom in several practical ways even if it were only to supply the appropriate equivalent word and its acceptable pronunciation. Another underestimated human resource already mentioned is peers. In some classes (again as in Vignette 1) learners seemed to have sufficient leeway to ask their classmates for clarification, while the seating arrangements in others allowed for peer interaction in the mother tongue, although this was not always acted upon.

The ant dilemma (Vignette 3) may also have been solved by code switching and is a powerful reminder of how much is taken for granted linguistically, even by second language speakers of a target language. The student teacher was taken aback by the learner's inability to draw a simple representation of an ant purely because he could not decode the English word. Her defense was that she had concentrated on teaching the musical term 'rhythm' and had assumed that since this insect was so familiar to all, everyone understood what the song was about. Here it is clear that teachers need to be more attuned to their role as teachers of 'language-across-the curriculum' and insure that even high-frequency words used during a lesson have been explained (Genesee, 1993). Furthermore, the purposeful use of visuals (or the actual insect) would have helped clarify meaning.

With regard to Vignettes 4 and 5 where visual material was used, albeit not correctly or appropriately, it is laudable that the teacher attempted to pay explicit attention to the local first language while storytelling and tried to link the written and spoken word using substituted text. However, the tension between the English labels and Tswana sounds as well as the incorrectly spelt words and open/shut mismatch create conceptual and linguistic confusion, underlining the point made earlier that language is the thread that ties teacher, text, materials, activity, use of space and learner together, within complex language encounters or, ideally, in the overall process of meaning making.

The final vignette (Vignette 6 - teaching the word 'oval') illustrates linguistic insecurity involving interrelated instructional predicaments: poor oral expression (not necessarily the same as proficiency) results in miscommunication and misunderstanding, while this inability to fluently express one's thoughts has resulted in a missed opportunity for incidental learning, and a bewildered learner. Here we believed that it would have been preferable for the teacher to keep explanations to a minimum since non-native English-speaking verbosity further confounded clarity of meaning.

Clearly, it would serve all teachers well to acquire a functional knowledge of classroom vocabulary and instructional phrases in a language spoken by the majority of learners in the class since having even a limited knowledge of the learners' home languages could go a long way towards improving academic and social understanding in the classroom. By attempting to communicate in the mother tongue the teacher demonstrates goodwill towards those learners and their language. This supports the aims of additive bilingualism and engenders respect for other 
languages while learners come to value their own mother tongue, and teachers enhance their cultural literacy (Evans, Gauton, Kaschula, et al, 2007).

Classroom and behavioural management is also facilitated if, at a more advanced level of proficiency, teachers are able to use both the instructional language and the learners' home languages in a systematic, purposeful process of code switching. Code switching thus provides a strategy for border crossing: it allows for meaning to be negotiated, for untranslatable ideas to be clarified and for children's home languages and cultural identities to be validated within the classroom (Arthur, 1994; 1996; Brock-Utne, 2003; Cleghorn, 1992; Cummins, 2003b; Eastman, 1992; Merritt, Cleghorn, Abagi \& Bunyi, 1992; Myers-Scotton, 1993).

Currently in South Africa there is no official oral assessment that establishes a teacher's proficiency in the language of instruction prior to taking up service. There is also no support network via which teachers can improve their spoken English. When teachers are compelled to teach via a language they do not know well, the tendency is to use non-communicative, rote 'safe talk' practices (Cleghorn, 2005; Cummins \& Hornberger, 2007; Hornberger \& Chick, 2001; Lightbown \& Spada, 2006; Park \& Sarkar, 2007). Although not evident from the vignettes presented in this article, we found much loud chanting and repetition as described by Wright's (2001) work in Eritrean classrooms. Safe-talk can also be seen in terms of the concept 'procedural display', in this case applied to teachers (Iannacci, 2006); that is, in the present study, chanting and repetition seemed to be audible proof (to colleagues and authorities outside the classroom) that the teacher was in fact teaching. On this point, Agnihotri (in Heugh et al, 1995, p. 6) suggests that the 'performance stress' that teachers unnecessarily endure may be minimized by switching to a more participatory and attentive role which would also permit learners to engage more meaningfully with the content. In this regard, as this research moves along it will be interesting to include a focus on teachers' questioning patterns, to see the extent to which these are restricted to repetition rather than reformulation or explanation, if procedural questions are asked, and if the teachers are able to engage the children in language reasoning activities.

Education for All (UNESCO, 2000) states that language is to be used to promote meaningful learning and to provide access to a language of wider communication for higher education and for global participation. Currently the quality of English being used for instruction in many of the South African classrooms with which we are familiar, is questionable, and raises concerns about whether all children have equitable access to meaningful learning. Apart from the obvious introduction of language support programs for learners, policy makers may consider the re-introduction of language endorsements for qualified teachers. This step could see all teachers regardless of learning area become fully proficient in the language of instruction. This could also extend to being conversationally fluent and literate in the first language of the learners they teach (Young in Heugh, et al, 1995, p.108).

In conclusion, without a high level of linguistic security in the instructional language teachers cannot adequately develop their learners' basic communicative skills nor their cognitive ability in that language. Knowledge about how young learners acquire second or additional languages is critical (Genesee, 2008; Lightbown \& Spada, 2006) while a cultural sensitizing and general language awareness training would further alleviate tensions evident in several of the classes we have observed so far. Although our findings as reported in this article are preliminary, they may already find practical application in terms of teachers' professional development and their language of instruction proficiency goals. The implementation of even small measures ought to insure improved social and pedagogical language encounters. 


\section{References}

Aikenhead, G. S. \& Jegede, O.J. (1999). Cross-cultural science education: a cognitive explanation of a cultural phenomenon. Journal of Research in Science Teaching, 36, 3, 269-288.

Alexander, R. (2000). Culture and pedagogy . London: Blackwell.

Anderson-Levitt, K. (2003) (Ed). Local meanings, global schooling: Anthropology and world culture theory. New York: Palgrave-Macmillan.

Arthur, J. (1994). Talking like teachers: Teacher and pupil discourse in Botswana primary classrooms. Language Culture and Curriculum, 7, 1: 29-40.

Arthur, J. (1996). Code-switching and collusion: Classroom interaction in Botswana primary schools. Linguistics and Education, 8, 17-33.

Bailey, K. M. \& Nunan, D. (1996). Voices from the language classroom. Cambridge: Cambridge University Press.

Bamgbose, A. (1984). Mother tongue medium and scholastic attainment in Nigeria. Prospects XVI, 1, 87 - 93, 1984.

Barton, D. (1995). Family literacy programmes and home literacy practices. Paper presented at the Literacies for the Future Symposium, University of Brighton, Lewes, U.K.

Barton, D., Hamilton, M. \& Ivanic, R. (2000). Situated literacies: Reading and writing in context. London: Routledge.

Benson, C. A. (2004). Bilingual schooling in Mozambique and Bolivia: from experimentation to implementation. Language Policy, 3, 47-66.

Bernhard, J. K., Diaz, C.F. \& Allgood, I. (2005). Research-based teacher education for multicultural contexts. Intercultural Education, 16, 3, 263-277.

Brandt, D. \& Clinton, K. (2002). Limits of the local: Explaining perspectives on literacy as a social practice. Journal of Literacy Research, 34, 3, 337-356.

Brock-Utne, B. (2003). The merits and problems of code-mixing and code-switching in the African classroom. Paper presented at the CIES, New Orleans, March 12-16.

Bunyi, G. W. (1999). Rethinking the place of African indigenous languages in African education. International Journal of Educational Development, 19, 337-350.

Cannella, G. S. \& Viruru, R. (2004). Childhood and post-colonisation: Power, education and contemporary practice. New York: Routledge Falmer.

Cleghorn, A. (1992). Primary level science in Kenya: Constructing meaning through English and indigenous languages. International Journal of Qualitative Studies in Education, 5, 4, 311-323.

Cleghorn, A. (2003). An ethnographic eye on text talk and teacher talk in developing country classrooms. Ways of Knowing, 3(1), 16-26.

Cleghorn, A. (2005). Language issues in African school settings: Problems and prospects in attaining education for all. In A.A. Abdi and A. Cleghorn, Issues in African education: Sociological perspectives (pp. 101-122) New York: Palgrave-Macmillan.

Cleghorn, A., Merritt, M. \& Abagi, O. (1989). Language policy and science instruction in Kenya. Comparative Education Review, 33, 1, 21-39.

Cleghorn, A. \& Prochner, L. (2010). Shades of globalization in three early childhood settings: Views from India, South Africa and Canada. Rotterdam: Sense Publications.

Cleghorn, A. \& Rollnick, M. (2002). The role of English in individual and societal development: A view from African classrooms. TESOL Quarterly, 36, 3, 347-372. 
Cobern, W.W. (Ed.), (1998). Socio-cultural perspectives on science education: An international dialogue. London: Kluwer.

Collison, G.O., (1975). Concept formation in a second language: A study of Ghanaian school children. Harvard Educational Review, 44 3, 441 - 457.

Collins, J. \& Blot, R. (2002). Literacy and literacies: Texts, power and identity. New York: Cambridge.

Cummins, J. (2003a). BICS and CALP: Origins and rationale for the distinction. In C. B. Paulston \& G. R. Tucker (Eds.), Sociolinguistics: The essential readings (pp. 322-328). London: Blackwell.

Cummins, J. (2003b). Challenging the construction of difference as deficit: Where are identity, intellect, imagination, and power in the new regime of truth? In P. Trifonas (Ed.), Pedagogies of difference: Rethinking education for social change (pp. 4160). London: Routledge.

Cummins, J. (1996). Empowering minority students: A framework for intervention. In T. Beauboef-Lafontant \& D. Smith Augustine (Eds.) Facing racism in education. $2^{\text {nd }}$ edition. Reprint Series No. 28, Harvard Educational Review (pp. 349-368). Cambridge, MA: Harvard Educational Review.

Cummins, J. (2000a). Language, power, and pedagogy: Bilingual children in the crossfire. Clevedon, England: Multilingual Matters.

Cummins, J. (2000b). "This place nurtures my spirit:” Creating contexts of empowerment in linguistically-diverse schools. In R. Phillipson (Ed.), Rights to language: Equity, power and education. (pp. 249-258). Mawah, NJ: Lawrence Erlbaum.

Cummins, J. \& Corson, D. (Eds.) (1997). Bilingual education. Vol. 5 Encyclopaedia of language and education. Dordrecht, The Netherlands: Kluwer.

Cummins, J. \& Hornberger, N. (Eds.).(2007). Encyclopaedia of language and education (2 $2^{\text {nd }}$ edition). New York: Springer.

Dachyshyn, D. \& Kirova, A. (2008). Understanding childhoods in-between: Sudanese refugee children's transition from home to preschool. Research in Comparative and International Education, 3, 3 281-294.

Dlamini, S.N. (Ed.) (2007). New directions in African education. Calgary: University of Calgary Press.

Eastman, C. (Ed.) (1992). Special issue on code switching. Journal of Multilingual and Multicultural Development, 13, 1-2, 1-17.

Egbo, B. (2000). Gender, literacy and life chances in Sub-Saharan Africa. Toronto: Multilingual Matters.

Evans, R., Gauton, R., Kaschula, R. Prinsloo, D. Ramagoshi, R. \& Taljard, E. (2007). Classroom literacies: Understanding your multilingual classroom. Thornton, S. Africa: Bateleur.

Gee, J. (1986). Orality and literacy: From The Savage Mind to Ways with Words. TESOL Quarterly, 20, 4, 719-746.

Gee, J. (1988). The legacies of literacy: From Plato to Freire through Harvey Graff. Harvard Educational Review, 58, 2, 195-212.

Gee, J. (2000). The New Literacy Studies: From "socially situated" to the work of the social. In D. Barton, M. Hamilton and R. Ivanic, Situated literacies: reading and writing in context. (pp. 180-196). London: Routledge.

Gee, J. (2008). Social linguistics and literacies: Ideology in discourses. N.Y.: Routledge. 
Genesee, F. (1993). All teachers are second language teachers. The Canadian Modern Language Review. 50, 1, 47-53.

Genesee, F. (2008). Dual language learning in the global village. In D. Tedick (Ed.). Pathways to multilingualism: Evolving perspectives on immersion education. (pp. 253-266) Clevedon: Multilingual Matters.

Ghosh, R. (1996). Redefining multicultural education. Toronto: Harcourt Brace.

Giroux, H. (1992). Border crossings: Cultural workers and the politics of education. New York: Routledge.

Heath, S. B. (1983). Ways with words: Language, life, and work in communities and classroom. Cambridge, Mass: Cambridge Press.

Heugh, K., Siegrühn, A., \& Plüddemann, P. (Eds.). (1995). Multilingual education for South Africa. Johannesburg: Heinneman Publishers (Pty) Ltd.

Hornberger, N. \& Chick, K. (2001). Co-constructing school safetime: Safetalk practices in Peruvian and South African classrooms. In M. Heller and M. Martin-Jones (Eds.) Voices of authority: Education and linguistic difference. Contemporary

Studies in Linguistics and Education, Vol. 1. Stamford, Connecticut: Ablex.

Hovens, M. (2002). Bilingual education in West Africa: Does it work? Journal of Bilingual Education and Bilingualism, 5, 5, 249-266.

Iannacci, L. (2006). Learning to 'do' school: Procedural display and culturally and linguistically diverse (CLD) students in Canadian early childhood education (ECE). Journal of the Canadian Association for Curriculum Studies, 4, 2, 55-76.

Kendrick, M. \& Jones, S. (2008). Girls' visual representations of literacy and identity in a rural Ugandan community. Canadian Journal of Education, 33, 1, 371-404.

Kim, J. (2003). Challenges to NLS: Response to "What's 'new' in New Literacy Studies. Current Issues in Comparative Education, 5(2), 118-121.

Krashen, S. D. (1982). Principles and practice in second language acquisition. New York: Pergamon.

Lightbown, P. \& Spada, N. (2006). How languages are learned. ( $3^{\text {rd }}$ edition). Oxford: Oxford University Press.

Mateche, H. Y. (1994). Role of mother tongue teaching in a bilingual or multilingual setting: The case of Malawi. Paper given at the Regional Conference on Teacher Education for Teaching Across the Curriculum. University of Zimbabwe.

Merritt, M., Cleghorn, A., Abagi, O. \& Bunyi, G. (1992). Socialising multilingualism: Determinants of code-switching in Kenyan primary classrooms. Journal of Multilingual and Multicultural Development, 13, 1/2, 103-121.

Myers-Scotton, C. (1993). Dueling languages: Grammatical structure in code-switching. Oxford: Clarendon Press.

Nsamenang, A.B. (2004). Cultures of human development and education: Challenge to growing up African. New York: Nova Science.

Olson, D. R. (1990). Mythologizing literacy. In S. Norris and L.M. Phillips (Eds.), Foundations of literacy policy in Canada. (pp.15-22) Calgary: Detselig.

Ong, W. J. (1991). Orality and literacy: The technologizing of the word. New York: Routledge.

Park, S. M. \& Sarkar, M. (2007). Parent's attitudes towards heritage language maintenance for their children and their efforts to help their children maintain the heritage language: A case study of Korean-Canadian immigrants. Language, Culture and Curriculum, 20, 3, 223-235. 
Peal, E. \& Lambert, W. (1962). The relation of bilingualism to intelligence.

Psychological Monographs, 76, 546.

Phillipson, R. (1992). Linguistic imperialism. Oxford: Oxford University Press.

Prinsloo, M. \& Breier, M. (1996). The social uses of literacy and practice. Philadelphia: Sacched.

Probyn, M. (2009). 'Smuggling the vernacular into the classroom': conflicts and tensions in classroom codeswitching in township/rural schools in South Africa. International Journal of Bilingual Education and Bilingualism, 12, 2, 123-136.

Prochner, L., Cleghorn, A. \& Green, N. (2008). Space considerations: Materials in the learning environment in three majority-world preschool settings. International Journal of Early Years Education, 16, 3, 189-202.

Ramanathan, V. (2005). The English-vernacular divide: Postcolonial language politics and practice. Clevedon, Avon, UK: Multilingual Matters.

Republic of South Africa (1995). White paper on Education and Training. Republic of South Africa (1997). Interim Policy for Early Childhood Development.

Republic of South Africa, (2001). Education White Paper 5 on Early childhood Education. Meeting the challenge of early childhood development in South Africa.

Serpell, R. (1993). Cultural models of childhood in indigenous socialisation and formal schooling in Zambia. In L. P. Hwang (Ed). Images of childhood (pp. 129-141) New Jersey: Lawrence Erlbaum.

Somjee, S. (2000). Oral traditions and material culture: An East African experience. Research in African literature, 31, 4, 97-103.

Soudien, C. (2007). Schooling, culture and the making of identity in contemporary South Africa. Cape Town: New Africa Books.

Statistics South Africa (2001) Census in Brief (No 03-02-03) Pretoria: Statistics South Africa.

Street, B. V. (2001a). Academic literacies: a critical perspective. Ways of Knowing Journal, 1(1), 19-23

Street, B. (2001b). (Ed.). Literacy and development: Ethnographic perspectives. London: Routledge.

Street, B. (2003). What's new in New Literacy studies? Critical approaches to literacy in theory and practice. Current Issues in Comparative Education. 5(2), 77-91. Street, B. (2004). Understanding and defining literacy: Scoping paper for EFA global monitoring report 2006. Unpublished manuscript.

Stromquist, N. P. (1997). Increasing girls' and women's participation in basic education. UNESCO: International Institute for Educational Planning. Stroud, C. (2002). Towards a policy for bilingual education in developing countries. Education Division Documents No. 10. Stockholm: Sida.

Stroud, C. 2007. Bilingualism: Colonialism, post-colonialism, and high modernity. In M. Heller (Ed.) Bilingualism: A social approach. (pp. 205-229), New York: Palgrave.

Sutton, M. (2001). Girls' educational access and attainment. In D. L. Hodgson (Ed.), Gendered modernities and ethnographic perspectives. (pp. 381-396) New York:Palgrave.

Tollefson, J. W. (1991). Planning language; planning inequality. New York: Longman. UNESCO (2000). Education for All.

UNESCO (2001). The plurality of literacy and its implications for policies and programmes. Education Sector Position Paper. 
UNESCO (2006). Education for All Global Monitoring Report, Literacy for life.

Waldrip, B.G. \& Taylor, P.C. (1999). Permeability of students' worldviews to their school views in a non-Western developing country. Journal of Research in Science Teaching 36(3), 289-304.

Wenger, E. (1998). Communities of practice: Learning, meaning and identity. New York: Cambridge University Press.

Williams, E. (1998). Investigating bilingual literacy: Evidence from Malawi and Zambia. London: DFID.

Wong-Fillmore, L. (1991). When learning a second language means losing the first. Early Childhood Research Quarterly, 6, 323-346.

Wright, M. (2001). More than just chanting: Multilingual literacies, ideology and teaching methodologies in rural Eritrea. In B. Street, Literacy and development: Ethnographic perspectives (pp. 61-77), London: Routledge.

\section{Author Biographies}

Ailie Cleghorn is professor in the Department of Education (Educational Studies) at Concordia University. Her background is in the Comparative Sociology of Education . She teaches Literacy and Development, Comparative Education and Methods of Research. Her most recent book, published in 2010 (with Larry Prochner, U. Alberta) is titled Shades of Globalization in three early childhood settings: Views from India, South Africa and Canada (Sense Publishers).

Rinelle Evans holds a PhD in curriculum and instructional design with special reference to instructional communication via television technology. She is currently a senior lecturer involved with teacher education in the Faculty of Education, University of Pretoria. Her academic interests relate to English language teaching, reflective practice, assessment, and bi-lingualism. 